212.20 .44

$u u-78-4-z$

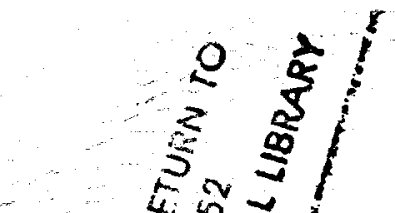

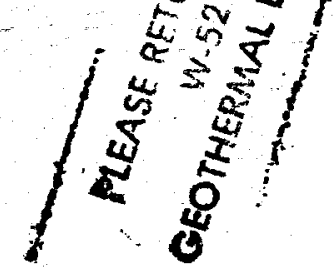

\title{
GEOLOGY AND GEOPHYSICS
}
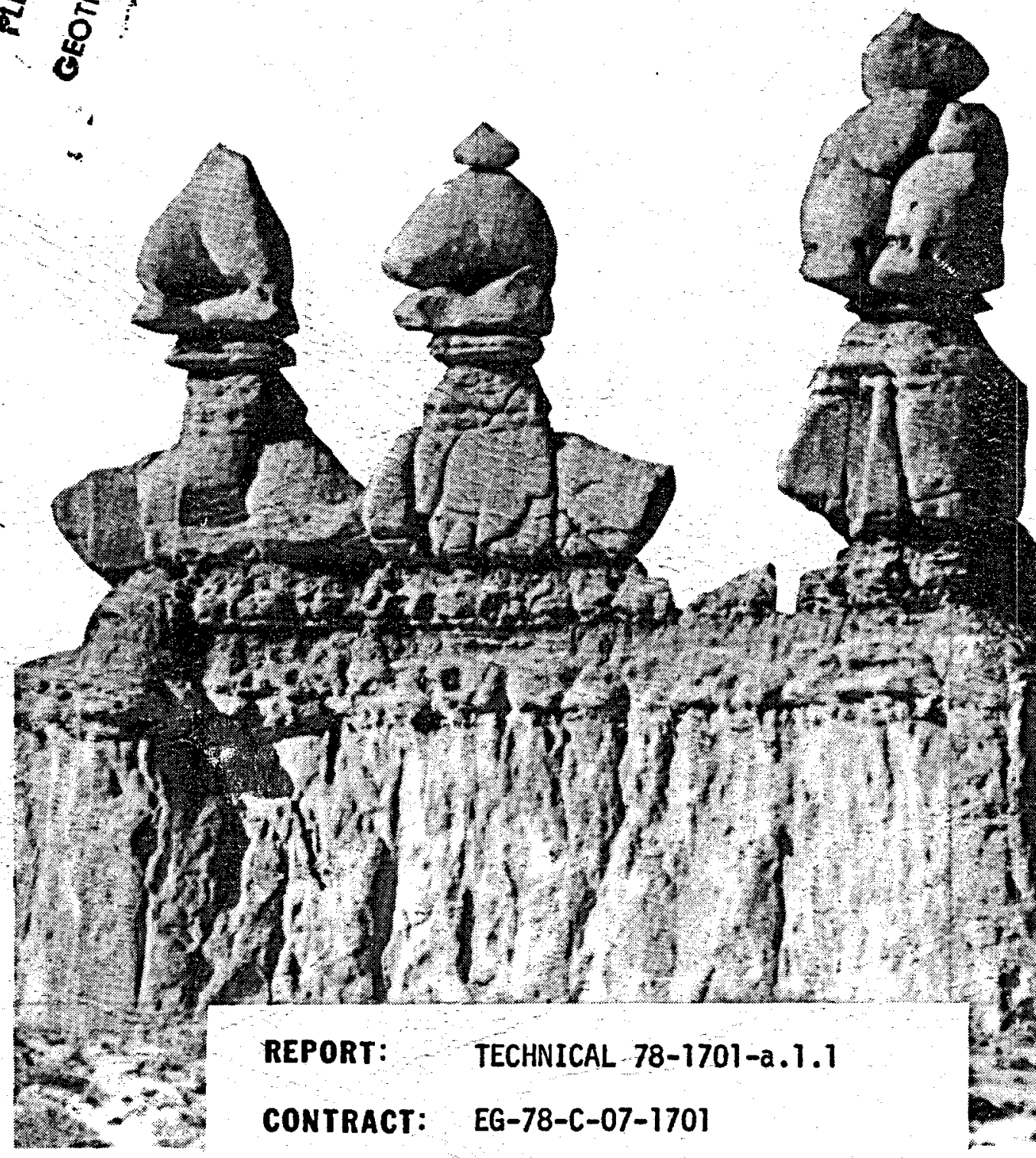

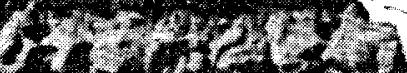

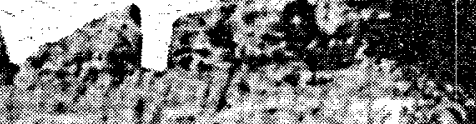

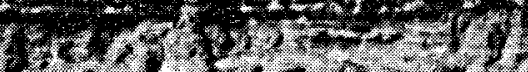

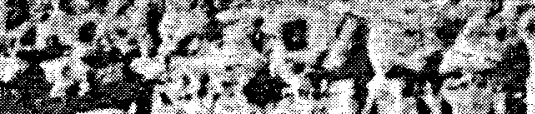

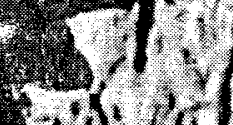

,

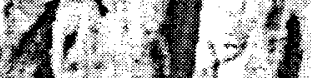

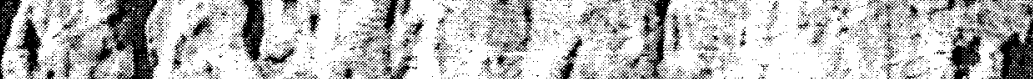

REPORT: TECHNICAL 78-1701-a.1.1

CONTRACT: EG-78-C-07-1701

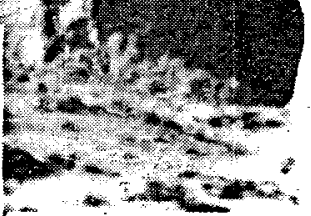

AGENCY: DOE/DGE

TITLE: SPRINGS THERMAL AREA, UTAH: PETROGRAPHIC CHARACTERIZATION OF THE ALTERATION TO 2 KILOMETERS DEPTH

AUTHORS: J. M. Ballantyne and W. T. Parry

$2^{2}$

DATE:

Apri1 1978 


\section{DISCLAIMER}

This report was prepared as an account of work sponsored by an agency of the United States Government. Neither the United States Government nor any agency Thereof, nor any of their employees, makes any warranty, express or implied, or assumes any legal liability or responsibility for the accuracy, completeness, or usefulness of any information, apparatus, product, or process disclosed, or represents that its use would not infringe privately owned rights. Reference herein to any specific commercial product, process, or service by trade name, trademark, manufacturer, or otherwise does not necessarily constitute or imply its endorsement, recommendation, or favoring by the United States Government or any agency thereof. The views and opinions of authors expressed herein do not necessarily state or reflect those of the United States Government or any agency thereof. 


\section{DISCLAIMER}

Portions of this document may be illegible in electronic image products. Images are produced from the best available original document. 


\section{Technical 78-1701-a.1.1}

DOE/DGE

EG-78-C-07-1701 
HYDROTHERMAL ALTERATION AT THE ROOSEVELT HOT SPRINGS THERMAL AREA, UTAH: PETROGRAPHIC CHARACTERIZATION OF THE ALTERATION TO 2 KILOMETERS DEPTH

J. M. Ballantyne and W. T. Parry 
CONTENTS

Page

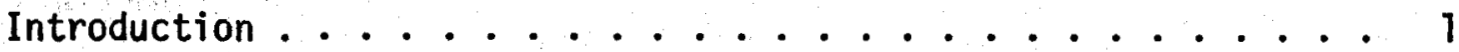

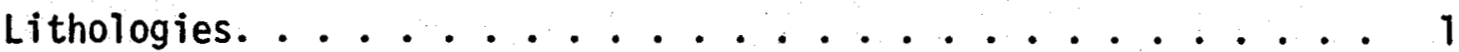

Biotite Hornblende Monzonite ........... 2

Microgranite .................... 4

Biotite Aplite Prophyry ............. 5

Biotite Hornblende Microgranite ..........66

Biotite Hornblende Apatite Dacite .......... 7

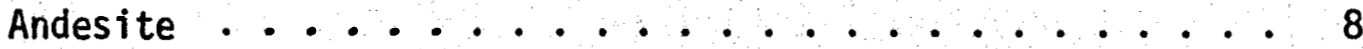

Crushed Fragments .............. 8

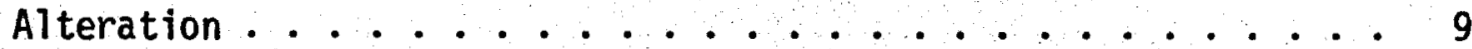

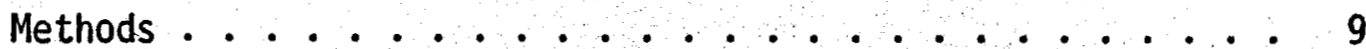

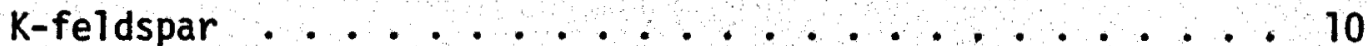

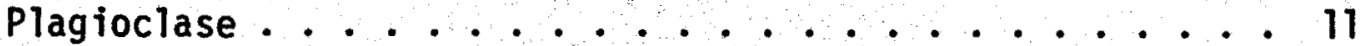

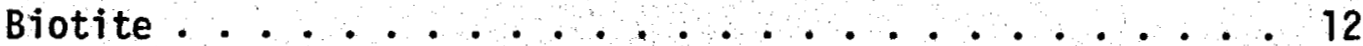

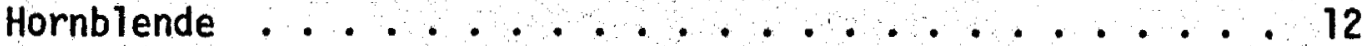

Sphene .................... 13

Anhydrite ................... 13

Sulfides ................... 14

Limonites ..................... 14

Vein Fillings .................. 15

Discussion ...................... 16

References ........................ 21

Appendix ...................... 22

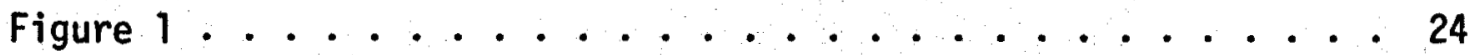




\section{INTRODUCTION}

Hydrothermal alteration in drill cuttings from Thermal Power drillhole 14-2, Roosevelt Hot Springs Thermal area, has been studied petrographically. The hole is sited in alluvium approximately $1.6 \mathrm{~km}$ southeast of the old Resort and was rotary drilled to a depth of $1866.0 \mathrm{~m}$. The exact hole location is $2310 \mathrm{FNL}, 350 \mathrm{FWL}$, Sec. 2, Twp 27S, Rge 9\$, elevation $1908.5 \mathrm{~m}$. Core was extracted from 792.5 to $795.5 \mathrm{~m}$. Thin sections were made from samples at $15.2 \mathrm{~m}$ intervals of drill cuttings collected at 1.5 or $3.0 \mathrm{~m}$ intervals during drilling. Thin sections were made of 1.5 or $3.0 \mathrm{~m}$ intervals from 274.3 to $304.8 \mathrm{~m}, 487.9$ to $581.2 \mathrm{~m}$, and 868.7 to $899.2 \mathrm{~m}$. These intervals were chosen for close spaced sampling on the bas is of increases in temperature, porosity, conductivity and acoustic velocity shown in geophysical logs. A total of 153 thin sections of cuttings were made, and an additional 9 sections were made from the core. Depths of thin section samples are listed in the appendix. A visual estimate of the percentage of each rock type was made for each thin section.

\section{LITHOLOGIES}

The hole was drilled in alluvium to $76.2 \mathrm{~m}$ and in intrusive igneous rocks from 76.2 to $1866.0 \mathrm{~m}$. The major rock type encountered is a medium grained biotite hornblende monzonite which has been intruded by a number of acidic and intermediate dikes. Dikes appear to be quantitatively most abundant in the upper part of the hole where acidic varieties predominate. Intermediate composition dikes occur throughout. 
A graphic lithologic log is included in Figure 1. Since samples are of rotary cuttings more than one lithology may be present in a thin section, and the log shows relative proportions of rock types. For presentation purposes the lithology in a 1.5 to $3.0 \mathrm{~m}$ sample at the top of a $15.2 \mathrm{~m}$ interval is shown to occupy the entire $15.2 \mathrm{~m}$ interval, except of course for more closely sampled intervals.

In the following lithologic descriptions mineral abundances are visual estimates. No point counts have been attempted.

Because of mineralogic similarities between the host biotite hornblende monzonite and the acidic dikes, distinction between host and dikes has often been difficult, particularly where both occur in the same sample. Thin dikes are probably more abundant than shown in the graphic log, Figure 1. Several acidic dikes which occur in the core sample would probably not be quantitatively significant enough to be recognized in a sample of rotary cuttings from the same interval. Also, small quantities of intermediate dike material are present in many thin sections, indicating that such dikes are more common than is shown in figure 1.

\section{Biotite Hornblende Monzonite}

The major rock type encountered in the drillhole is a light colored, medium grained, granitic textured biotite hornblende monzonite which probably corresponds to the granite (Tg.) of surface maps. Visually estimated mineral abundances are:

$\begin{array}{lc}\text { K-feldspar } & 40 \% \\ \text { Plagioclase } & 40 \% \\ \text { Biotite } & 10-12 \%\end{array}$


Quartz

Hornblende

Sphene

Apatite

Zircon

Allanite (?)

Opaques
$5 \%$

$1-2 \%$

$2 \%$

tr.

tr.

rare tr.

tr.

Microcline is the K-feldspar polymorph above $610 \mathrm{~m}$; cross-hatch twinning was not observed below this depth. Perthite is ubiquitous and occurs as three textural types, all of which may appear in the same sample. The most abundant perthite type consists of nearly equant blocks, sometimes with straight sides, and usually with albite twinning. The second perthite variety forms as clusters of tiny parallel rods with tapered ends. A third perthite type consists of irregular elongate lamellae, occasionally albite twinned, which appear to be less common than the other types. Rare small equant quartz crystals are also present. All types occur throughout the hole, though not all may be present in one sample.

Plagioclase occurs as subhedral grains .5 to $2 \mathrm{~mm}$ in size, and is commonly partly altered to sericite \pm calcite, chlorite, K-feldspar, clay, epidote and hematite.

Biotite forms clusters of crystals .5 to $1 \mathrm{~mm}$ across with width to height ratios of greater than 2 .

Hornblende occurs as subhedral crystals, sometimes poikilitically enclosing quartz and apatite. Throughout most of the middle portion of the 
hole original hornblende replaced by fine grained assemblages of sericitecalcite-clay-leucoxene, or chlorite-calcite-quartz-leucoxene.

Quartz tends to be finer grained than feldspars or mafics, and to fill interstices between them.

Accessory minerals are subhedral to anhedral. Sphene often poikilitically encloses apatite, zircon and opaques. Sphene has of ten been completely altered to leucoxene, calcite and quartz. Sphene ranges up to $2 \mathrm{~mm}$ in size, and apatite, zircon and the rare allanite up to $.5 \mathrm{~mm}$.

\section{Microgranite}

Dikes of a light pink equigranular microgranite occur between 487.7 and $640.1 \mathrm{~m}$, through parts of 685.8 to $823.0 \mathrm{~m}$, and between 1371.6 and $1386.8 \mathrm{~m}$. Thin dikes up to 3 inches wide are present in core near 792.5 $\mathrm{m}$ and may be common throughout the drillhole.

Composition is estimated as:

K-feldspar

$40 \%$

Plagioclase $30 \%$

Quartz $30 \%$

Biotite $2 \%$

Sphene

tr.

Apatite

tr.

Zircon

tr.

Opaques

tr.

Allanite

rare

Mineral grains are anhedral to subhedral, quartz and feldspars often with irregularly sutured margins, and quartz grains are often multicrystalline. 
Felsic minerals are commonly .5 to $1 \mathrm{~mm}$ in size. Biotite flakes are thin, and less than $.5 \mathrm{~mm}$ across. No exsolution of plagioclase in K-feldspar has occurred, nor was microcline twinning observed.

At dike margins in the core, a spotty replacement texture occurs where rounded or elongate blebs of quartz have partially replaced feldspars. This spotted texture is also present in some samples of cuttings.

\section{Biotite Aplite Porphyry}

A light colored fine grained rock with phenocrysts of plagioclase, quartz, and occasional K-feldspar occurs between 106.7 and $152.4 \mathrm{~m}$. A fine grained, somewhat banded rock of similar composition is also observed between 1097.2 and $112.5 \mathrm{~m}$.

Phenocrysts are anhedral, usually .5 to $1 \mathrm{~mm}$ across, in a groundmass of rounded quartz grains and anhedral K-feldspar and plagioclase .05 to .1 $\mathrm{mm}$ across.

Estimated composition is:

\begin{tabular}{lr} 
K-feldspar & $30 \%$ \\
Plagioclase & $25 \%$ \\
Quartz & $40 \%$ \\
Biotite & $5 \%$ \\
Sphene & $\mathrm{tr}$ \\
\hline Apatite & $\mathrm{tr}$ \\
\hline Zircon & $\mathrm{tr}$ \\
\hline Opaques & $\mathrm{tr}$ \\
\hline
\end{tabular}


No exsolved plagioclase or cross twinning is observed in K-feldspar. Biotite is green-brown, rather ragged, and has a width to height ratio of greater than 2.

\section{Biotite Hornblende Microgranodiorite}

A fine grained subequigranular biotite hornblende microgranodiorite occurs between 292.6 and $365.8 \mathrm{~m}$.

The estimated composition is:

\begin{tabular}{lr} 
K-feldspar & $20 \%$ \\
Plagioclase & $30 \%$ \\
Quartz & $30 \%$ \\
Hornblende & $10 \%$ \\
Biotite & $10 \%$ \\
Apatite & $2 \%$ \\
Sphene & $1 \%$ \\
\hline
\end{tabular}

Feldspar and quartz grains commonly have dimensions of about $.5 \mathrm{~mm}$. K-feldspar does not exhibit any exsolution or twinning.

Quartz is distinctive in that it forms irregularly shaped multicrystalline aggregates $.5 \mathrm{~mm}$ across made up of crystals less than $.1 \mathrm{~mm}$ in size. Mafic minerals are commonly .1 to $.3 \mathrm{~mm}$ across, and hornblende is usually replaced by aggregates of fine grained greenish or brownish clay minerals and sericite.

Apatite occurs both as needles and as large $(.1 \mathrm{~mm})$ subhedral crystals. Sphene is usually .2 to $.3 \mathrm{~mm}$ across. 


\section{Biotite Hornblende Apatite Dacite}

Fine grained dikes of intermediate composition all containing relatively high percentage $(2-3 \%)$ of apatite needles and of sphene $(3 \%)$ occur throughout the drillhole. Compositions actually range from andesite to quartz latite. The dikes contain between 13 and $30 \%$ mafic minerals including biotite and hornblende, and in three samples clinopyroxene. The pyroxene has been altered to fibrous amphibole, biotite, carbonate, magnetite and minor fine grained quartz.

The range of grain size in these dikes is usually .03 to $.3 \mathrm{~mm}$.

The most commonly occuring dike type is a dacite. Above $610 \mathrm{~m}$ and at $1249.7 \mathrm{~m}$, greater quartz and $\mathrm{K}$-feldspar percentages almost place these dikes in the quartz latite compositional range. At 876.3 and $1356.5 \mathrm{~m}$ low quartz and $\mathrm{K}$-feldspar abundances and the presence of pyroxene mark the dikes as andesites. A fine grained altered dike at $1158.2 \mathrm{~m}$ is probably the same rock type. Samples on either side of 876.3 contain chips of a dacitic rock type.

The dikes have been grouped into four compositional types. Typical compositions for each group are given below, together with the depths at which each type occurs.

\begin{tabular}{lrrrr} 
Depth (meters) & 1249.7 & 1356.4 & 838.2 & 396.2 \\
& & 1158.2 & 1432.6 & 289.6 \\
& & 876.3 & 1508.8 & 167.6 \\
& & & 1844.0 & \\
K-feldspar \% & 20 & 1 & 10 & 25 \\
Plagioclase \% & 30 & 60 & 60 & 40 \\
\hline Quartz \% & 20 & - & 5 & 15 \\
\hline
\end{tabular}




$\begin{array}{lrrrr}\text { Biotite } \% & 20 & 5 & 5 & 10 \\ \text { Hornblende } \% & 5 & 25 & 15 & 3 \\ \text { Pyroxene } \% & -- & 5 & - & - \\ \text { Apatite } \% & 2-3 & 2-3 & 2-3 & 3 \\ \text { Sphene } \% & 3 & 3 & 3 & 3\end{array}$

Andesite

A very fine grained rock composed of feldspars, chlorite, micas, clay, leucoxene and opaques occurs in small quantities at several locations. Pyroxene may also be present.

Crushed Fragments.

Fragments of stained, crushed, felsic mineral aggregates occur in small quantities throughout the drillhole. Their origin is unknown. They may be breccia adjacent to fractures along which tectonic movement has occured. 


\section{ALTERATION}

Hydrothermal alteration has affected all rocks in the drillhole. Original rock textures are generally preserved. Significant changes in alteration mineralogy and intensity are observed which do not appear to be rock-type dependent.

\section{Methods}

Alteration was described in three ways: pervasive alteration mineralogy was described by determining the alteration products of each of the major mineral species, vein and fracture fillings were described where recognized, and intensity of alteration was described by estimating the amount of destruction of major mineral species. Because of the nature of the samples (cuttings) the relationships of mineralogy and intensity to veins and fractures cannot be determined, but overall patterns clearly emerge. Detailed results of the alteration study are presented in Figure 1.

Pervasive alteration mineralogy in any one sample varies from chip to chip, and each chip or grain may not have all of the alteration products ascribed to that sample.

Variations in alteration intensity and also in mineralogy are likely to be caused largely by variations in distance from fluid carrying veins and fractures. Vein and fracture fillings and altered selvedges have however been difficult to recognize in the cuttings. Fine grained chips of quartz, K-feldspar, or banded or compositionally zoned material have usually been ascribed to veins, as have chips composed of calcite. 
Alteration intensity has been determined for plagioclase by estimating the range of percent destruction of plagioclase within a sample. This range is shown as a bar for each sample on Figure 1, and a curve of maximum plagioclase destruction is shown linking samples on Figure 1. This curve provides a semi-quantitative measure of relative alteration intensity in the drillhole. For biotite, hornblende and sphene only a qualitative measure of alteration intensity is given. Within any one sample unaltered, partly altered, and totally altered grains of a mineral species may occur. The presence or absence of grains in each state of destruction is shown on Figure 1.

Detailed descriptions of alteration of each mineral type are presented below.

Note that on Figure. 1 the alteration assemblage in the top 1.5 or $3.0 \mathrm{~m}$ of a $15.2 \mathrm{~m}$ interval is shown to represent the entire $15.2 \mathrm{~m}$ interval, except for the closely sampled regions.

\section{$\underline{\text { K-feldspar }}$}

Primary K-feldspar may not have been hydrothermally altered at all. Perthite exsolution textures are present in the biotite hornblende monzonite host rock as described earlier, but were not observed in any of the dikes. Different perthite morphologies may have been formed at different times and one type at least may have exsolved during reheating by the geothermal system. 


\section{Plagioclase}

Both intensity and mineralogy of plagioclase alteration vary markedly with depth in the drillhole. Three zones of intense alteration are recognized, in which plagioclase may be totally replaced. These occur at 274.3 to 304.8 $\mathrm{m}, 487.7$ to $581.2 \mathrm{~m}$, and 868.7 to $899.2 \mathrm{~m}$. Mineralogy is described below.

Sericite replacing plagioclase is almost ubiquitous and commonly occurs as fine disseminated flakes, and particularly in more intensely altered plagioclase as masses or stringers. Coarser grain size is also apparent in the more intensely altered zones. Between approximately 610 and $730 \mathrm{~m}$, al though intensity is relatively weak, occasional radial clusters of coarse sericite occur.

Calcite occurs sporadically above $499.9 \mathrm{~m}$ as occasional small patches in plagioclase. Between 499.9 and $655.3 \mathrm{~m}$ calcite was not observed but at deeper levels it becomes much more abundant and widespread.

$\mathrm{K}$-feldspar is present as small patches in plagioclase above 487.7 and below $670.6 \mathrm{~m}$. Although secondary $\mathrm{K}$-feldspar is present throughout the lower portion of the drillhole, it tends to be rare in weakly altered rocks.

Chlorite, except for rare occurrences between 292.6 and $365.8 \mathrm{~m}$, does not replace plagioclase above $716.3 \mathrm{~m}$. Below this point chlorite forms stringers and patches of fine grained, pale green, low birefringent crystals. Minute crystals of hematite are commonly disseminated in plagioclase above $716.3 \mathrm{~m}$.

Rare brownish mica flakes were observed in plagioclase at $167.6-442.0 \mathrm{~m}$. 
Epidote in plagioclase is rare, but does occur between 152.4 and 365.8 $\mathrm{m}$ and also at 1371.6 and $1783.1 \mathrm{~m}$ as tiny clusters of anhedral crystals.

Clay al teration of plagioclase was not easily recognized in thin section. However, x-ray diffraction patterns of clay fraction smears show the presence of montmorillonite between 228.6 and $502.9 \mathrm{~m}$. This is probably a plagioclase alteration product. Mixed layer clays appear in XRD patterns above $198.1 \mathrm{~m}$, between 381.0 and $624.8 \mathrm{~m}$, and are a1so tentatively recognized between 1112.5 and $1234.4 . \mathrm{m}$.

\section{Biotite}

Primary biotite in all rock types is brown to brownish green.

Chlorite commonly replaces biotite. Above $853.4 \mathrm{~m}$ chlorite is present in only very small amounts, but below this depth and down to $1386.8 \mathrm{~m}$ most biotite has been partially or totally chloritised. Below $1386.8 \mathrm{~m}$ chlorite continues to be present but replaces only a small proportion of biotite crystals.

Epidote in small quantities accompanies chlorite below $990.6 \mathrm{~m}$.

A light green coloration of biotite grains is common above $853.4 \mathrm{~m}$ but rare at lower levels. This coloration is apparently due to bleaching by hydrothermal solutions. Both bleached and chloritised biotite may occur in the same sample.

Hornblende

Light green hornblende occurs in the host monzonite and in several of the dikes. Alteration products are fine grained and of two distinctive types. Above $792.5 \mathrm{~m}$ hornblende has been altered to light green or colorless 
sericite \pm calcite, brown clay and minor leucoxene. Bright apple green sericite stringers are sometimes present, apparently formed along original cleavages. Below $992.5 \mathrm{~m}$ the alteration products of hornblende are fine grained chlorite, calcite, leucoxene and occasional fine grained quartz.

Throughout the middle section of the drillhole between 425 and $1370 \mathrm{~m}$ almost total destruction of original hornblende has occurred. Above and below this interval unaltered or only partially destroyed crystals predominate. Where the biotite hornblende apatite dacite dikes occur, chips are common with totally destroyed hornblende and with unaltered hornblende in the same sample.

\section{Sphene}

Sphene occurs in most rock types. A1 teration products are leucoxene, calcite and quartz. Often only pseudomorphs of the original mineral remain. Magnetite and pyrite are common associates of sphene, often enclosed within the sphene grain or as pseudomorphs. Pyrite appears to have replaced primary magnetite which has been poikilitically included in the sphene.

Almost total destruction of sphene has occurred between 553 and $823 \mathrm{~m}$ and also between 960 and $1356 \mathrm{~m}$.

\section{Anhydrite}

Anhydrite occurs sporadically in small amounts below $1524 \mathrm{~m}$ as one or several crystals in or adjacent to plagioclase. Crystals are up to .1 mm in size and of ten exhibit (011) twinning. No anhydrite veins were seen. 


\section{Sulfides}

Opaque minerais were identified using reflected light. Pyrite is the only sulfide mineral definitely identified. Chalcopyrite was tentatively identified at four locations.

Pyrite occurs in two main associations: as a replacement product of primary magnetite, and as disseminated grains in plagioclase. One vein pyrite occurrence was noted in drill core at $795.01 \mathrm{~m}$. Pyrite does not replace biotite or hornblende except in rare cases. Pyrite grains are usually anhedral but equant.

Above $701 \mathrm{~m}$ pyrite, though present, rarely occurs in abundances of more than 1 or 2 grains per thin section. However, the common presence of limonites above this level may be due to oxidation of original pyrite. Between 701 and $853 \mathrm{~m}$ up to 10 grains per thin section were noted, and between 853 and $1463 \mathrm{~m}$ more than 20 grains are common. Below $1463 \mathrm{~m}$ abundance decreases to less than 20 grains per section (much less than $1 \%$ ).

\section{Limonites}

Minor hematite staining was noted in thin sections to persist to 716.3 m. Throughout most of the hole some magnetite has a reddish tinge in reflected light suggesting partial oxidation to hematite.

Limonite is common in the upper part of the hole, and often forms veins, sometimes with calcite. Limonite also of ten cements small brecciated aggregates of fragments of feldspar and quartz \pm biotite. 
Vein fillings

A number of different types of vein fillings are recognized in the drillhole, and some broad patterns of vein mineralogy are developed.

Vein fillings include quartz, K-feldspar, calcite, chlorite and sericite, all of which may occur alone or in combination with other minerals. Accessory vein filling materials include montmorillonite, clays, pyrite, magnetite, hematite, (?) leucoxene, epidote, gypsum and possibly barite. These accessory minerals are not common, and epidote, barite and gypsum were noted only once.

Several veinlets were noted in the drillcore: a quartz-calcite vein in a microgranite dike, a quartz-calcite-sericite-leucoxene vein, another with minor barite and with quartz-sericite-clay selvedges, and a magnetiteK-feldpsar-chlorite-pyrite vein. A1l except the first listed are in biotite hornblende monzonite.

Calcite occurs in veins throughout the drillhole, alone or in combination with other minerals. Quartz and K-feldspar are common vein fillings above $1280 \mathrm{~m}$. Chlorite is noted in veins between 731.5 and 914.4 feet, but only rarely below this depth. Vein montmorillonite (?) was noted near 274.3 $\mathrm{m}$ and at $1295.4 \mathrm{~m}$. Sericite and/or undifferentiated clays were seen between 487.7 and $883.9 \mathrm{~m}$, and at 1615.4 and $1706.9 \mathrm{~m}$. Gypsum was tentatively recognized at $1432.6 \mathrm{~m}$ and barite at $1037.55 \mathrm{~m}$ in core. Vein pyrite was seen in core at $795.19 \mathrm{~m}$ and in cuttings at 579.1 and $1097.3 \mathrm{~m}$. 


\section{DISCUSSION}

Six different rock types have been recognized in the drillhole, including three acidic and two intermediate dike varieties. Intermediate dikes, the dacitic and andesitic groups, probably correspond to the Tertiary mafic dikes of surface maps. The acidic dikes may correspond to the Tertiary aplite dikes of surface maps, they may be related to the Quaternary rhyolitic volcanism, or to both or neither of these events. Chemical comparisons and/or age dating are required to solve this problem.

Drillhole intervals chosen for closely spaced sampling were chosen on the basis of increases in temperature and in the geophysical parameters porosity, conductivity, and acoustic velocity. Alteration intensity is high in these zones and throughout the drillhole appears to correlate most strongly with increased porosity, though broad correlation with temperature increases are seen. High alteration intensity also correlates with the presence of acid dikes: microgranodiorite between 295.7 and $381.0 \mathrm{~m}$ and microgranite between 487.7 and $640.1 \mathrm{~m}$. However, other dike occurrences do not appear to have such an association. The regions near the upper contacts of the two dikes mentioned show increased porosity, conductivity and acoustic velocity.

The problem of separating fossil al teration from that related to the current geothermal system has not yet been resolved. There may be little or no fossil alteration. An apparent alteration mineral zonation about the 
microgranite dike does exist, but whether the zoning is actually about the dike or about a zone of increased permeability is not evident. In the microgranite dike between 487.7 and $640.1 \mathrm{~m}$ sericite, together with hematite is the only alteration product of plagioclase. Biotite is bleached in the dike, chlorite after biotite is present on either side, and after plagioclase only within about $120 \mathrm{~m}$ on either side of the dike.

The low overall abundance of alteration minerals in DDH 14-2 compared to systems such as Wairakei and Ohaki-Broadlands in New Zealand (Steiner, 1968, Browne and Ellis, 1970) and Reykjanes, Iceland (Tomasson et al., 1972) may be due mainly to differences in host rocks. At Roosevelt the major rock types are medium grained, crystalline plutonic varieties while the systems noted above occur in fine grained, dominantly pyroclastic, volcanic material with higher porosity than crystalline intrusive rock. At Ohaki-Broadlands welded tuffs and ignimbrites with low porosity exhibit little alteration despite high temperatures.

Alteration products of primary minerals in Roosevelt DDH $14-2$ are similar to those found in other geothermal systems. At Ohaki-Broadlands hornblende and biotite are replaced by chlorite, illite, calcite, quartz or pyrite (Browne and Ellis, 1970) and at Wairakei ferromagnesian minerals are altered to chlorite, micaceous clays, quartz, calcite, epidote, apatite and pyrite (Steiner, 1968). At Steamboat Springs hornblende goes to mixed illitemontmorillonite and Fe-chlorite. Biotite is first bleached and then pseudomorphed by chlorite (Schoen and White, 1965). Original biotite and hornblende are not reported from Reykjanes or from the Salton Sea. Pyrite after 
ferromagnesian minerals is not observed in DDH 14-2 at Roosevelt, and apatite, though present in altered hornblende, is assumed primary since it also occurs in fresh hornblende.

A range of plagioclase alteration products is reported from different geothermal systems. Browne and Ellis (1970) report that andesine at OhakiBroadlands is replaced by adularia, albite, calcite, illite, wairakite, epidote and quartz. Plagioclase at Wairakei has been converted to a variety of hydrothermal minerals including montmorillonite, micaceous clays, calcite, wairakite, albite, K-feldspar, quartz and epidote (Steiner, 1968). At Steamboat Springs plagioclase is replaced by illite-montmorillonite, calcite, albite, and at shallow depths by K-feldspar (Schoen and White, 1965).. Specific descriptions of plagioclase alteration products are not reported for Reykjanes or the Salton Sea, but albite and epidote occur in plagioclase at Reykjanes (Tomasson et a1. 1972). In the Roosevelt system wairakite and albite have not been recognized in plagioclase, and chlorite and hematite are common alteration products, in addition to those reported from other systems. The presence of iron oxide in plagioclase in the upper part of DDH 14-2 may indicate that albitisation has occurred. Albite at Ohaki-Broadlands is clouded by iron oxides presumably because of the low solubility of $\mathrm{Fe}$ in Na-feldspar relative to $\mathrm{K}$ - and Ca-rich feldspar (Browne and Ellis, 1970). At lower levels the Fe appears to have been incorporated into chlorite in DDH 14-2.

Zeolites have not been identified in Roosevelt DDH 14-2. However since zeolites most commonly fill fractures and cavities at other systems their 
apparent absence at Roosevelt could be due to sampling procedure. Much of the vein filling material has probably been lost from the cuttings.

Secondary K-feldspar which replaces plagioclase and also occurs as a vein filling is assumed to be adularia because of its paragenesis. The morphological characteristics which commonly distinguish adularia were not noted in plagioclase replacements, though some of the vein $\mathrm{K}$-feldspar exhibits variable extinction. No x-ray determinations have been made.

Epidote is a minor constituent in DDH $14-2$ and is also a common constituent at depth in other systems. A difference between Roosevelt DDH 14-2 and other systems however, is the presence of epidote at two levels in DDH 14-2. Epidote occurs in small quantities in plagioclase in the upper part of DDH 14-2, is absent in the middle portion of the hole, and at lower levels occurs after biotite along with chlorite and at still greater depths reappears in plagioclase.

Anhydrite is a very minor constituent in the lower portion of DDH 14-2, and is also a common, if minor, constituent at Reykjanes and at the Salton Sea (Tomasson et a], 1972, Muffler and White, 1969). Anhydrite is not reported from New Zealand geothermal fields.

A feature of DDH $14-2$ is its low total sulfide content, considerably less than 1\%, and its apparent lack of sulfide minerals other than pyrite, except for four unconfirmed chalcopyrite sightings. However, limonite is abundant in the upper part of the drillhole and may reflect greater original sulfide content than that downhole. 
Sphene, a primary mineral at Roosevelt, is reported as an alteration mineral at the Salton Sea by Muffler and White (1969).

Acid sulfate alteration assemblages are present elsewhere in the Roosevelt geothermal system but are not discussed in this report.

No discussion of physicochemical controls of alteration mineralogy is included in this report./Characterization of the mineral chemistry and the development of a geochemical model to explain observed alteration mineral zonations are subjects of the ongoing study at Roosevelt

J. M. Ballantyne and W. T. Parry

Feb. 78 


\section{References}

Browne, P. R. L. and Ellis, A. J., 1970, The Ohaki-Broadlands hydrothermal area, New Zealand: mineralogy and related geochemistry: Am. J. Sci. v. 269, p. $97-131$.

Muffler, L. J. P., and White, D. E., 1969, Active metamorphism of Upper Cenozoic sediments in the Salton Sea geothermal field and the Salton Trough, Southeastern California: Geol. Soc. America Bull., v. 80, p. 157-182.

Schoen, R. and White, D. E., 1965, Hydrothermal alteration in GS-3 and GS-4 drillholes, Main Terrace, Steamboat Springs, Nevada: Econ. Geology, v. 60, no. 7, p. 1411-1421.

Sigvaldason, G. E., 1963, Epidote and related minerals in two deep geothermal drillholes, Reykajavik and Hveragerdi, Iceland: U.S. Geol. Survey Prof. Paper 450-E, p. 77-79.

Sigvaldason, G. E., and White, D. E., 1962, Hydrothermal al teration in driltholes GS-5 and GS-7 Steamboat Springs, Nevada: U.S. GeoT. Survey Prof. Paper 450-D, p. 113-117.

Steiner, A., 1968, Clay minerals in hydrothermally altered rocks at Wairakei, New Zealand: Clays and Clay Minera 1s, v. 16, p. 193-213.

Tomasson, J. and Kristmannsdottir, H., 1972, High temperature alteration minerals and thermal brines, Reykjanes, Iceland: Contr. Mineral. and Petrol. v. 36, p. 123-124. 


\section{APPENDIX}

DDH 14-2 Thin Section Samples

Depths in feet

\section{Cuttings}

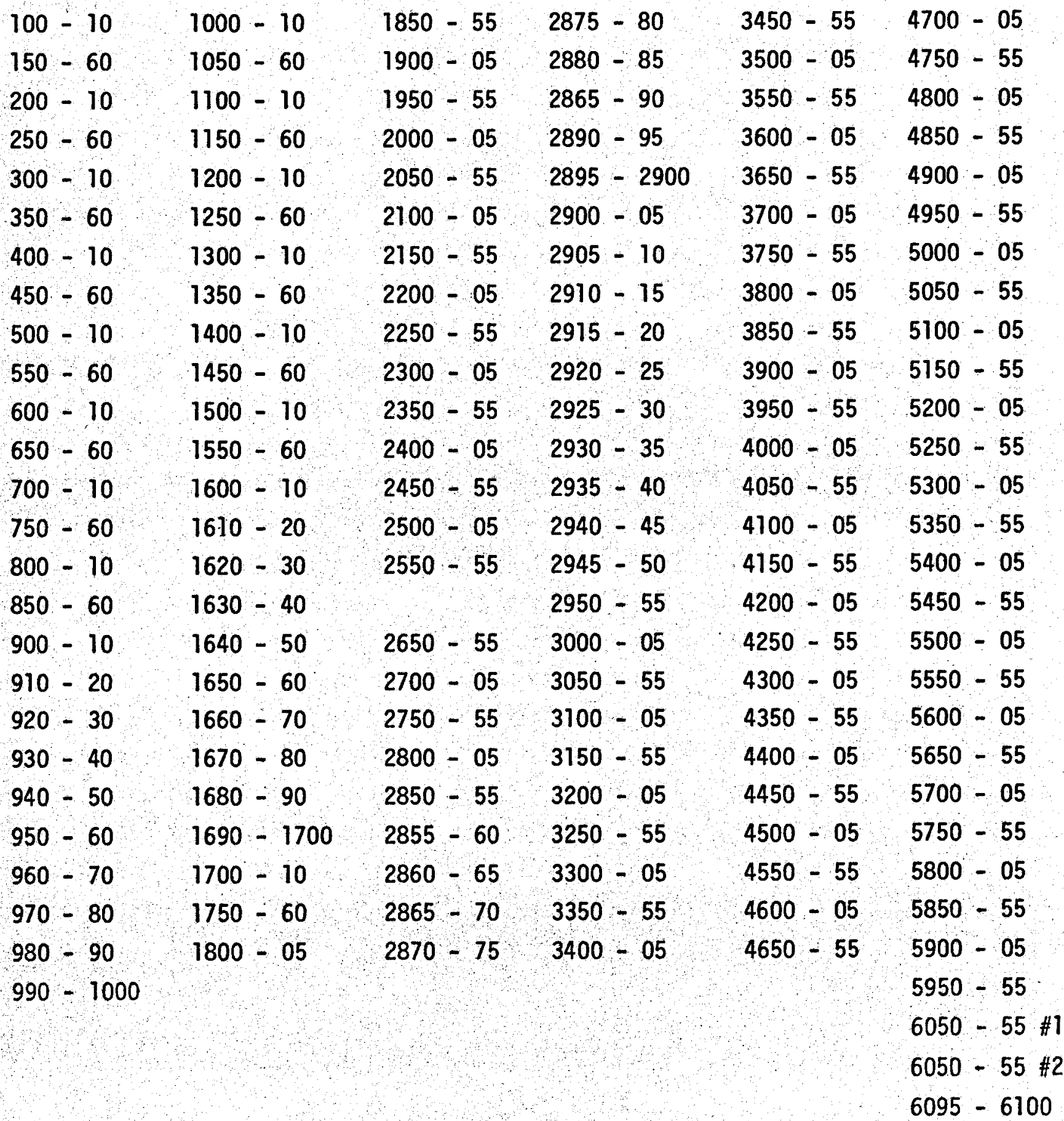


Core

$2600^{\prime} 3^{\prime \prime} \quad 2603^{\prime} 9^{\prime \prime}$

$2601^{\prime} 9^{\prime \prime}$ A 2607' 6"

$2602^{\prime} 3^{\prime \prime} A \quad 2608^{\prime} 9^{\prime \prime}$

$2603^{\prime} 3^{\prime \prime}$ B $2608^{\prime} 1^{\prime \prime}$ 
Figure 1. Hydrothermal alteration in Roosevelt Hot Springs ODH 14-2. Abbreviations: B, barite; C, chalcopyrite; $\mathrm{Ca}$, calcite; Ch, chlorite; $\mathrm{Cl}$, clay; Gy, gypsum; H, hematite; K, K-feldspar; Mo, montmorillonite; Mt, magnetite; Py, pyrite; Q, quartz; S, sericite; Ti, leucoxene. 


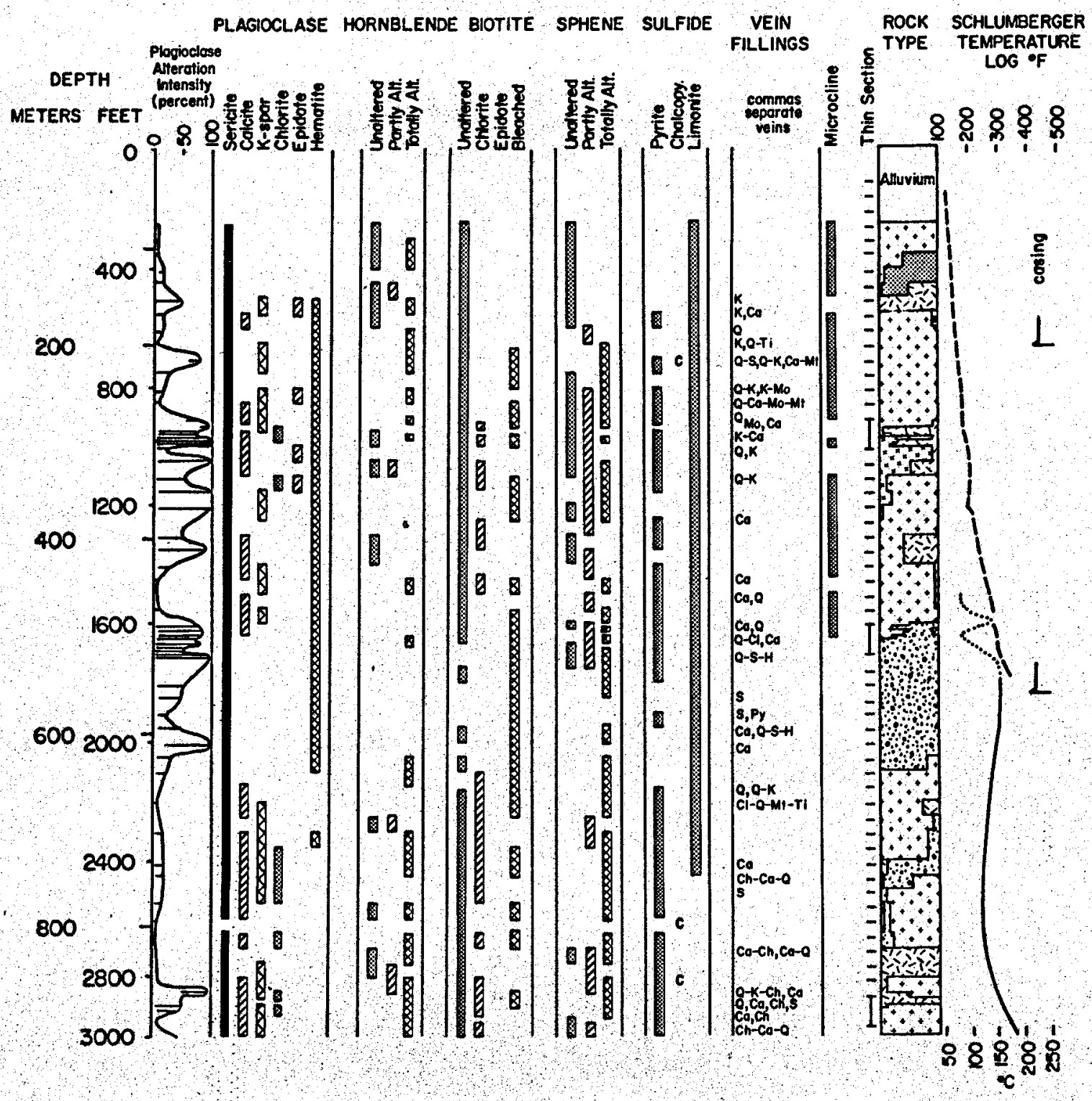




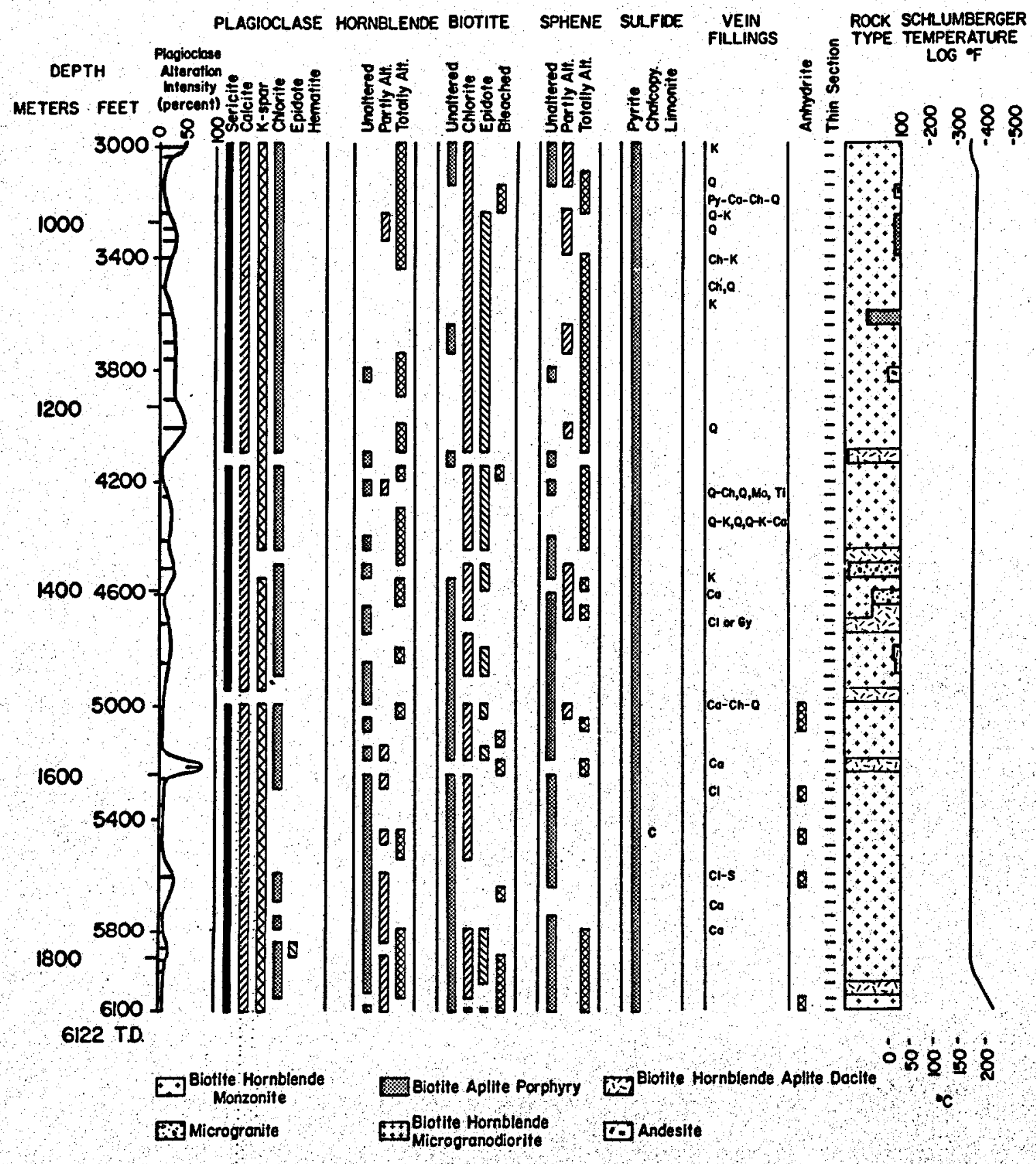

